\title{
Status of School Library Development in Pakistan
}

\author{
Dr. Muhammad Ramzan \\ Chief Librarian \\ Lahore University of Management Sciences \\ Opposite Sector "U" \\ Defence Housing Authority \\ Lahore Cantt. 54792 \\ Pakistan \\ Tele: +92 425722670 Ext. 4109, Cell 923004487844 \\ Fax: +92 425898307 \\ E-mail: mramzan@lums.edu.pk URL: www.lums.edu.pk
}

\section{Introduction}

The constitution of the Islamic Republic of Pakistan accepts education as one of the fundamental rights of a citizen, and our government has a commitment to provide access to education to every citizen. However, the literacy rate is still estimated as $54 \%$ which is low as compared to other South Asian countries with a similar level of economic development. The basic or school education covers pre-school, primary, middle, secondary, higher secondary and technical secondary education and above that is higher education up to $\mathrm{PhD}$ level. According to the official Pakistan Education and School Atlas for the year 2003, there were 182,636 schools in the country, of which 149,280 were in the public sector and 33,356 in the private sector. Of these, 142308 were primary schools, 25,461 middle schools and 14,867 higher and higher secondary schools.

As per rules it is important for any academic institution whether public or private in Pakistan to have a library within its premises to support teaching and learning. Federal Board of Intermediate and Secondary Education (FBISE) Act of 1975, says that an institution seeking affiliation with the board, must have:

- Accommodation for library in the school building

- The school shall have a well stocked library. In case of new schools a sum of Rs. 25,000 must be spent on the library in the first year and a provision to the extent of Rs. 5,000 must be made in every year's budget.

- Adequate number of newspapers and periodicals must be provided in the reading room

- The school shall have a Library Assistant who must have obtained a certificate / diploma in library science

The number of libraries is currently not known According to a survey conducted in 1990s out of 171,000 schools, only 481 schools have libraries containing 980,800 volumes. Only 30 librarians are placed in the school libraries. About $80 \%$ schools are without any library facility in the country. National Education Policy 1998-2010 targeted to establish and strengthened one library in each school by the year 2010. It also planned the provision of adequate funds, buildings, library periods, etc. to maximize the use of school libraries in the country 
The private schools run by different chain systems, trusts, companies and organizations, are English medium, usually located in urban areas, and expensive. More than $95 \%$ of these have moderate school libraries equipped with a wide range of books, audio visual and IT facilities and magazines available for students to read and borrow.

The private schools run by individuals or by groups of people are located in suburban and rural areas to cater for the educational needs of students belonging to lower middle class families use rented building, and they do not possess libraries.

The schools for most of the lower middle class in rural areas and the poor class in urban areas are run by the government. The situation of most of the public sector school libraries is poor. There is no concept of libraries in primary and middle schools. Only a few books are kept in closed cupboards in one of the offices, or in another multipurpose room. Students are seldom allowed to borrow or study library books. The situation in high and higher secondary schools is better, where the number of books is in at least in hundreds; a teacher or clerk acts as library in charge and in some cases librarians manage the libraries. They usually acquire popular books (religious, fiction, poetry, or stories), reference books or highly scholarly books chosen by the headmaster or teacher in charge.

Library periods are also observed in some schools and students are allowed to read and borrow books. However, the timings of the libraries are the same as of the school, so very little time is available for the students or teachers to avail the library facility.

\section{Administration and co-ordination system of school libraries in Pakistan}

The structure of educational administration in Pakistan is reflective of the broader public administration system. The Federal Ministry of Education acts as both a technical resource and as a channel of communication on the national education policy to the provinces. It provides both control and guidance on curriculum, text books and standards. Department of Libraries (National Library of Pakistan) acts as an advisory body on library affairs for Federal Ministry of Education. However, no specific role has been designated to the National Library of Pakistan as a national library policy-making institution.

Provincial education departments implement programs and policies and formulate provincial policies and procedures. In the Devolution Plan 2001, the responsibility for the delivery and management of school education has shifted to the district governments. Provincial Education Department is headed by a Provincial Education Minister. The civil servant in charge of the department is the Provincial Education Secretary. The hierarchy then runs down to the Special Secretary Schools, Executive District Officer, District Education Officer (DEO). Then there are two DEOs, one deals with elementary education and takes care of primary and middle schools and the other dealing with secondary education deals with the high and higher secondary schools. At the grass root level (union Council level), Learning Co-coordinators (LCs) provide academic guidance as well as supervise the schools, however head master in each school is executive officer and head of the school. A teacher of a clerk is made incharge of the library. In some higher secondary schools professional librarian manage the affair of the library. 
The library in charge reports to the head master, who enjoys all administrative and financial powers. There is no library professional or library qualified person in the provincial headquarters to look after or advise on school library affairs to the government of the incharge school libraries.

There is no specific budget for school libraries. Headmasters use union fund; which is primarily a school development fund, to purchase newspapers and some books for the library. Some time secretary education or other officials sitting in provincial governments buy bulk copies of few titles and sent to the headmasters for their libraries.

Hierarchy of library administration

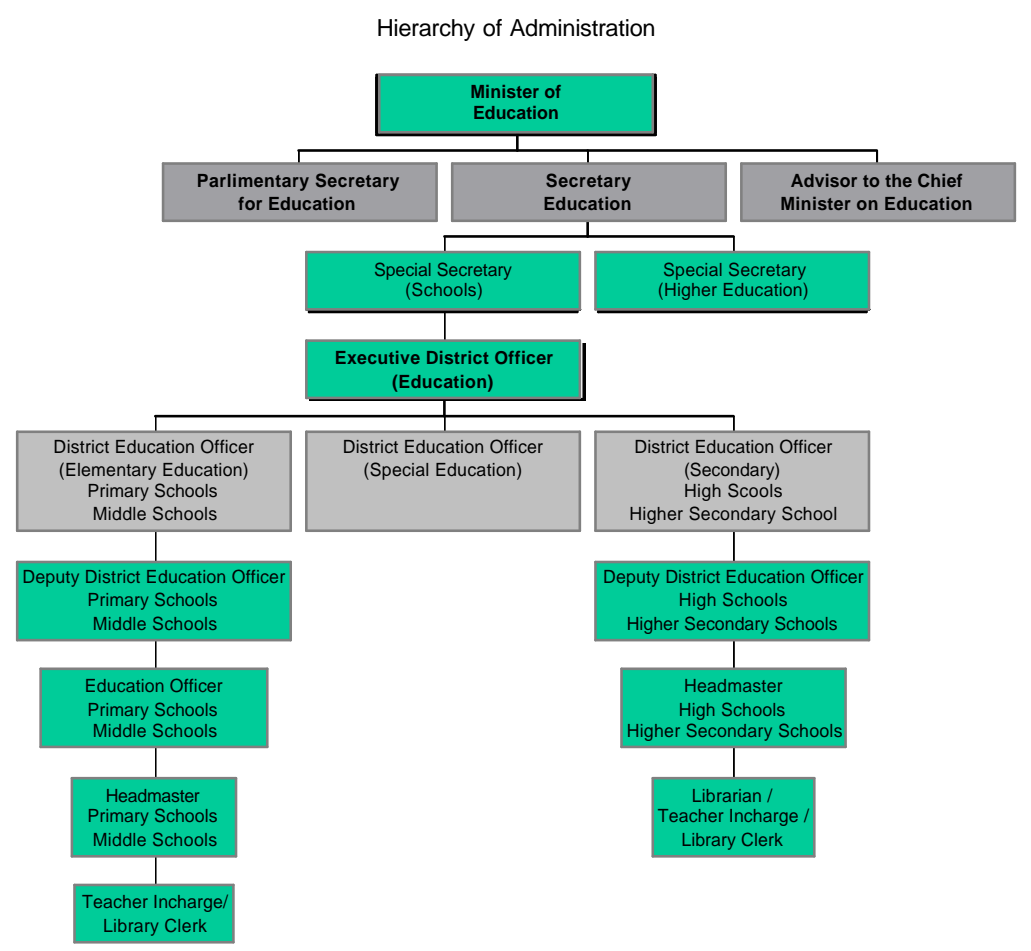

\section{Problems and issues of school libraries}

School libraries, where they exist, are usually used in free time these are not embedded in our teaching and learning system. Three major problems school libraries confront are listed below:

There need to be an understanding and legislation to ensure that each school possess a library with a reading room, adequate number of school level books, furniture and multimedia facilities. Provision of school library budget, its proper utilization and monitoring will ensure the updating and maintenance of these libraries. The provision of the school library should be a legal requirement for establishment or existence of any school. The size of the library may differ keeping in view the number of student population. 
Hardly any library possesses its own building. Space provided for the library is limited, where library functions cannot be performed properly. Un-functional arrangement of space and stock, unhealthy atmosphere discourage the reading habits of the children.

As far as the educational and professional qualifications are concerned, uniformity does not exist. Non-qualified staffs, like teacher incharges are discharging library duties as additional service without any allowance or facility. Non-qualified staff and untrained teacher incharge of library cannot perform technical services. It is necessary to appoint professionals with library training so that libraries are managed properly.

Here are some common problems identified by library professionals time to time:

- Teaching and learning process in our schools does not encourage use of libraries. Mostly it is text book or memory based learning system in our schools. That does not require use of libraries either by the students or by teachers.

- School library is not treated as an integral part of school teaching

- The library is considered as the last item on the school priority list

- A teacher who is slow or undesirable is made responsible for the library

- Purchase of books is treated as a contingency item, or if a grant is provided book are bought at random.

- There is no selection policy and no one is responsible to select or suggest books for the library except the headmaster or headmistress

- There is no regular provision for libraries in the annual budget

- Books found in the libraries are either highly scholarly or terribly poor

- Books purchased for the libraries are not according to the subjects taught in schools but represent the interests or tastes of the headmasters or teacher librarians

- Students do not have access to the library. Only those who hold a good opinion of the teacher-librarian get books from the library

- Usually, in most of the schools the library is opened during the vacant hour of the teacher librarian

- Book cupboards are locked

- Teachers are always reluctant to accept this responsibility since in case of loss of books they may have to pay from their own pocket

There is a need to have a department to look after the school libraries and to initiate and implement a school library development project in the country or at the provincial level.

\section{School library development projects}

Presently no projects are being supported by the World Bank or any such body for the development of school libraries in Pakistan. A few other projects directly / indirectly impacting school libraries development are listed below:

Following policy provisions and physical targets were set by the Government of Pakistan for school libraries development:

- To establish, maintain and upgrade (where they exist) school libraries in every primary, middle, higher and higher secondary schools by 2010

- To equip each school library with the latest reading materials /services

- To allocate a compulsory library period in each school 
- To provide Internet connection with computer to each library

- To ensure regular funds allocation for the development and extensive use of library facilities

National Education Policy 1998-2010 also recommended the following steps for the promotion and development of school and other libraries in the country:

- Book banks shall be established in academic libraries for a free textbook service to needy students $A$ comprehensive library and information services policy shall be introduced through an Act of Parliament in the country and service conditions of library professionals and staff shall be further improved

- Every school will have a library

- A library period shall be introduced in the school timetable

- For the formulation of library standards, and legislation, expert committees shall be formed. For conducting training courses and surveys, annual grant shall be ncreased accordingly

- A libraries development fund shall be increased from $0.2 \%$ to a reasonable level to achieve the policy targets

No data is available to evaluate the status or impact of the National Education Policy on school or other libraries.

\section{Education Sector Reforms (ESR) 2001-02 to 2005-06}

ESR is based on long term national agenda of the Government of Pakistan and is linked with Education For All (EFA) goals by the year 2015. One of the objectives of this project is "improvement in the quality of education at all levels through better teachers. Upgraded training options, curriculum and textbook reforms, and competency based examination system for promoting Pakistan as knowledge based society." It aims at achieving the $60 \%$ literacy target by 2005 . ESR has assigned a central place to school education. The original ESR package was proposed at a cost of Rs. 55.5 billion for the years 2001-04. The duration of this project has been extended up till 2005-06 due to non-availability of resources and to accommodate the President's program for missing facilities and decentralized training facilities, mainstreaming of madaris and setting up of polytechnics at Tehsil level at an estimated cost of Rs. 100 billion. International funding agencies like US AID, DFID, CIDA, JICA, EU, G8, International NGOs, and expatriate Pakistanis are the main funding partners with the Government of Pakistan for implementation of this biggest ever education reform program. World Bank and Asian Development Bank are also providing loans for this project. In this whole project there is no direct mention of setting up or upgrading school libraries. No data is available of the indirect effect of this project on school libraries in Pakistan.

\section{Education For All (EFA)}

EFA was designed to ensure that by 2015 all children in the country could complete a quality primary education. It was part of an ongoing global campaign being run by UNESCO. Education For All National Plan of Action has been developed for the period of 2001-2015 at an estimated cost of Rs. 430 billion. To achieve the target of education for All children by 2015 primary education has been declared compulsory by all the provinces except Balochistan. In 2003, the World Bank announced that it would assist the Punjab Government in providing buildings, libraries, electricity and drinking water to schools. 